\title{
Opportunity to Foreign Investor in Kosovo
}

\author{
Nakije Kida \\ $\mathrm{PhD}$ (C) European University of Tirana, Republic of Kosovo, Pristina.
}

\begin{abstract}
Purpose of the study is descriptive analysis of questionnaires investment of Kosovo. The main findings of important contributions to the literature on the effects of FDI on economic growth are highlighted. In the short and longterm, FDI do not cause an increase in Kosovo. On the other hand, FDI have been directed to the services sector (with low added value). This proves that the aggregate effect of increasing investments is unclear because different institutional components (business climate, weak enforcement of law, corruption, etc.), have hindered the attraction of FDI. Identifying determinants of FDI, are important for compiling of FDI promotion policy of certain types to contribute to the growth.
\end{abstract}

Keywords: FDI; Kosovo investment, Obstacles, Opportunities to Foreing Investment in Kosovo, Descriptive analysis.

\section{Introduction}

There are more and more investor searchers of efficiency and resources present in Kosovo. Since Kosovo has a cheap labor force and multiple natural sources, investor expectations will become reality only if the business climate, improves as well as the functioning and good governance of institutions. If we have a historical look at FDI in Kosovo since 2004, when the first official statistics appear, (since in 2000-2003, FDI are presented together with private investments, not including public investments IMF., 2004), they have an upward trend that shows that Kosovo has benefited from FDI, covering the gap of capital lack in the country, which gap was greatly helped through foreign donations and privatization. The data of CBK (2014), estimated that in 2004, net FDI amounted 42.9 million entered Kosovo, though symbolic, economic growth is stimulated primarily by FDI in the sector of services, creating the first subsidiaries of the banking system and insurance companies, real estate, consultancy etc. Net FDI inflows in 2005 were 107.6 million euros, continuing a positive pace in 2006 with 294.8 million euros, in 2007 with 440.7 million euros, in 2008 the trend fell to 366.5 million, in 2009 with 287.4 million, in 2010 with 365.8 million, in 2011 with 393.9 million, in 2012 with 229.1 million and in 2013 in value of 259.4 million euros. By 2004 FDI were 42 million euros, considered the lowest in the region. Even after 14 years, their rates have not increased much. They are considered to have reached their peak in 2007 with 440.7 million euros, but the positive trend suffered constant decrease up to 2014. The decrease is due to the unfavorable environment for doing business and other negative phenomena, such as weak implementation of law, corruption and insufficient development of the country's general infrastructure, especially roads, energy, etc. However despite this decrease of FDI and the global eurozone crisis, the economy of Kosovo has the highest economic growth in Europe by increasing the average growth globally not lower than 3\% by the year 2014 . While the average growth for 15 years is $4 \%$, but measured as annual $\%$, has declined in about $3 \%$ for all these years.

\section{Review of the literature}

The literature offers no clear predictions about the effects of FDI, growth and economic development. Creating the conditions by the host country to welcome FDI should be one of the main activities, investment promotion, etc. The IMF defines foreign investment as "direct" when an investor holds abroad 10\% or more of the assets of an enterprise, enough to give investors a measure of control in its management. The literature on FDI is multiple:

- UNCTAD (1999) noted that the positive effects of FDI on economic growth depends on the performance of countries in terms of GDP per capita, level of education, level of domestic capital, political stability, the terms of trade and the level of financial development.

- Moreover, Borensztein et al. (1998:115-135) and Driffield (2004:163) found that FDI has a direct effect on economic growth in a country, Markusen (1999) reported a positive relationship between FDI and economic growth (cited:Khalid Al Khathlan. 2013. Pg.7. ). 
- Balasubramanyam et al. (1996) uses data crossbar for 46 countries for the period 1970 - 85 to analyze the relationship between FDI and economic growth. Their results show that FDI has a positive impact on the economic development of those countries that have pursued internal strategies on research and development (cited by Nabila Asghar., Samia Nasreen., Hafeez ur Rehman., 2011. Pg. 84-86) .

- Charkovic and Levine (1998:1-23) use as panel and cross-section data for 72 developed countries and developing countries for the period 1960 to 1995 to analyze the relationship between FDI and economic growth. Through OLS and GMM estimation methods there is no positive relationship between FDI and economic growth.

- Alfaro (2003:1-32) is of the opinion that the benefits of FDI differ in sectors and the impact of FDI in the primary sector is negative while it is positive in the manufacturing sector and ambiguous in the services sector.

- Choe (2003:44-57) finds limited evidence in both directions of the correlation FDI/Growth and concludes that the interpretation of causality between growth and FDI remains highly controversial.

- good institutions that ensure property rights, guarantee political stability and weaken corruption, promote a better investment climate.

However, the empirical literature has been left behind (it has not reached a consensus yet) and there have been many problems to identify advantages in practice.

\section{Research methodology}

This chapter uses the primary data (quantitative approach), provided through instruments (questionnaires). From the population of 1369 foreign investors, it has been chosen the sample of 306 foreign companies with $100 \%$ foreign capital (leaving aside investors with mixed capital, according to KSA. 2014, there are 3721 in total). This analysis provides the opinion of foreign companies operating in Kosovo about the opportunities and plans for their investments. Due to descriptive analysis is achieved the testing of the hypothesis "Opportunities encountered by foreign investors while investing in Kosovo", from structured data obtained through the survey face to face and via e-mail. There are 306 companies selected randomly. The face to face questionaire was used in 200 surveys, while 106 questionaires were conducted via emails (for a period of 3 months, October December 2014). Therefore the exemplar includes a total of 306 respondents with accuracy of $95.5 \%$ in the total sample of 1369 companies with 100\% foreign capital in Kosovo.

\subsection{Sampling}

The study population comprises foreign investors in Kosovo. The study sample comprises foreign investors with $100 \%$ foreign capital. The sample is random, representative sample of the entire population of foreign investors with $100 \%$ foreign capital. The population in this study is 1369 Foreign Investors, enough to survey 306 foreign investors. For example, the recommended sample size for a population of 1500 , a confidence level of $95.0 \%$, and a margin of error (degree of accuracy) of 5\% would be 306. A sample is obtained of $\mathrm{N}=306$, [the Research Advisors (2006)], sufficient, despite the failure of 194 companies (out of the planned sample of 500 investors).

\subsection{The content of questionnaires}

The survey includes options and plans of foreign companies to invest in Kosovo. The questionnaire consists of 12 modules on relevant topics:

Planning in the future to invest in Kosovo,

How attractive to invest you classify the general situation in Kosovo,

How do you rate the level and quality of information about the business environment in Kosovo,

* How were you informed about Kosovo, what is your area of interest to invest,

* What attracts you in Kosovo,

* Is this the first time you've invested in Kosovo,

* Will you riinvest again, do you have a certain date for an additional investment,

* What are the reasons you hesitate to invest,

* What special incentives you would prefer from the Government of Kosovo, additional comments. 


\section{Result Descriptive analysis}

\subsection{Opportunities and plans of foreign investors to invest in Kosovo}

More investor searchers of efficiency and resources are present in Kosovo. Since Kosovo has a cheap labor force and multiple natural sources, investors' expectations will become reality only if the business climate and functioning and good governance of the institutions is improved.The questionnaire presents opportunities that Kosovo has for foreign investors and their plans for future investments.

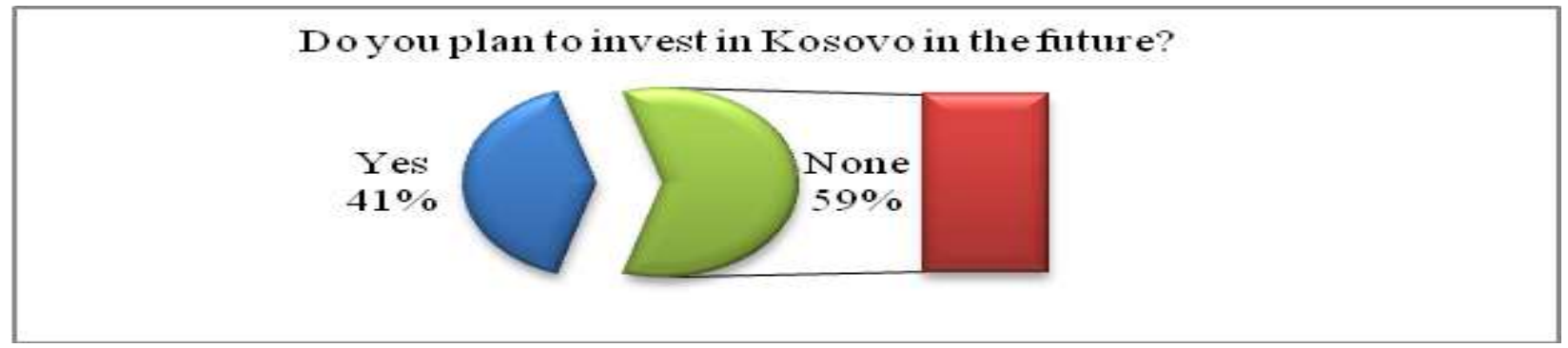

Fig. 1: Future plans to invest in Kosovo.

- Future plans to invest in Kosovo, are not in favor of increasing investment (by actual investors). From this perspective, in 2015 is expected a decline of FDI, so we need to stimulate new investors with new incentives from those that already exist. Failure to create concrete incentives on time (investors are interested what and where the country offers to invest), loses the opportunity for new investors to come, and those who are already in Kosovo are likely to run to neighboring countries. The quote of 41 percent of investors declared to invest in Kosovo, is discouraging that Kosovo expects foreign capital to replenish the lack of domestic one. Whereas, the answer of 59 percent of investors that they are not likely to invest in Kosovo but elsewhere, is worrisome for government institutions which should create more favorable conditions in the country.

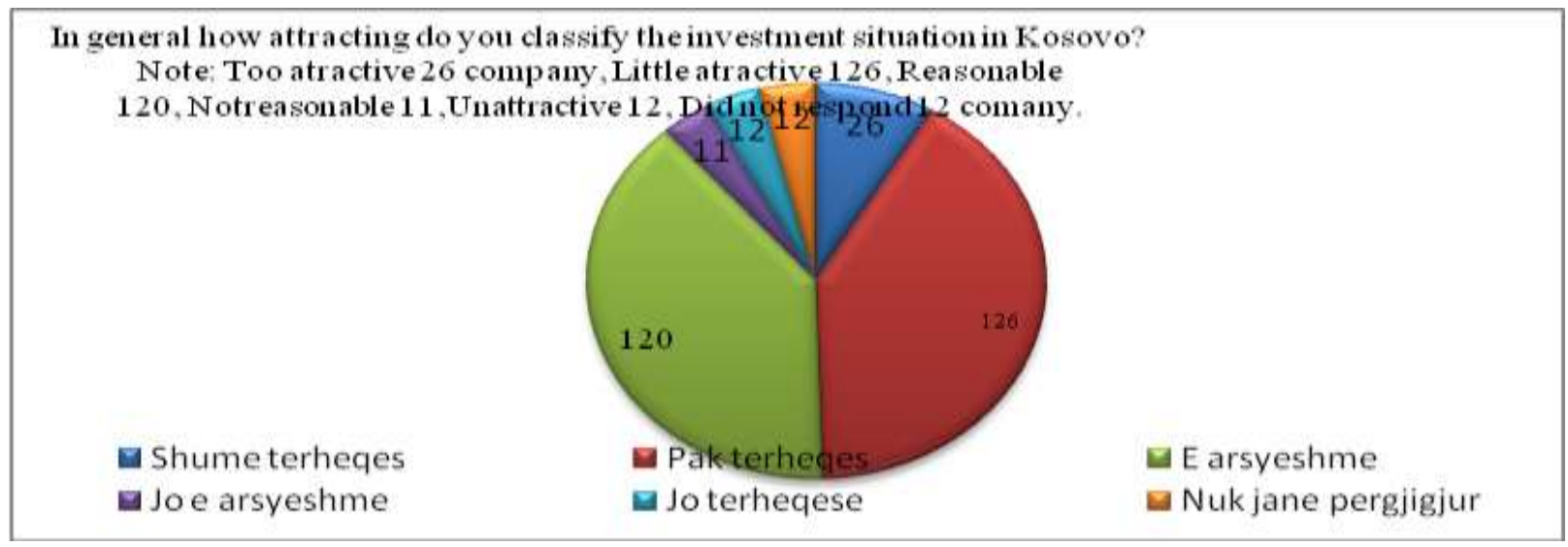

Fig. 2: How attracting is the investment situation in Kosovo.

- Rough-Value planned to invest in Kosovo, investors in Kosovo were asked about the amount they will invest in 2015, and 171 investors or 55.8 percent of them will invest again in Kosovo. The rest of the 135 or 44.1 per cent of investors prefer not to invest. The largest amount of investment will be $1-2.5$ billion euros ( 3 or 0.9 percent of foreign companies). 55 companies or 17.9 percent of them will investthe amount of 1 - 63 million, while 50 companies or 16.3 percent of them from 10 thousand to 900 thousand euros.

- Information quality about the business environment in Kosovo, from total of 306 surveyed respondents, 58 percent of companies consider the quality of information partly satisfying, mainly satisfying 15 percent of companies, and fully satisfying 1 percent of them. This positive rating of 74 percent is very encouraging, which shows that we are working towards fair and fast informing of foreign investors about Kosovar business environment. The quote of 26 percent of investors are not satisfied (23\% not satisfied and 3\% fully dissatisfied), noting that there is no transparency in contact with local companies and institutions. 


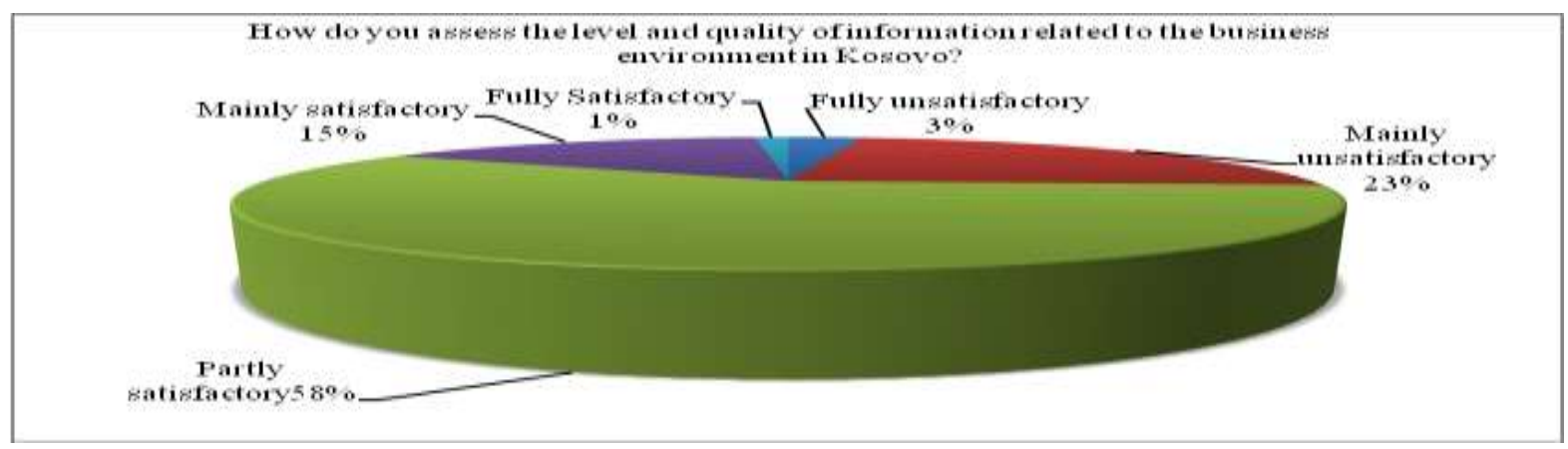

Fig. 3: Information quality about business environment in Kosovo

- Your area of interest to invest,it is considered that the aims of 48 percent of investors are directed towards the sector of the roadconstruction, agriculture 9 percent, tourism 7 percent, railway transport 7 percent, textile industry 5 percent, road transport 4 percent, hotels and restaurants 3 percent, food industry 3 percent, banking7 percent, mining 2 percent, and other activities 8 percent. The interest to invest in the low and high construction sector is related to the high demand of providing housing in urban areas and the high price per $\mathrm{m}^{2}$. The infrastructure projects of public investments have also stimulated the interest of foreign companies to turn to investment in low construction (roads). Even in the agriculture sector the government has signaled that it will subsidize investors if they invest in this sector. Besides financial assistance on provision of the soft loans, it will help investors with tariff exemptions on customs and value added tax on imports and new machinery for the first 6 months. There are also signals that there will be tax holidays for the first six months of work. There will also be legislative changes on the planned reforms in favor of the investors, additional subsidies for this sector because it is considered a sector that provides employment opportunities in the remote rural environments. The tourism and textile industriesare the goals of investors, too.

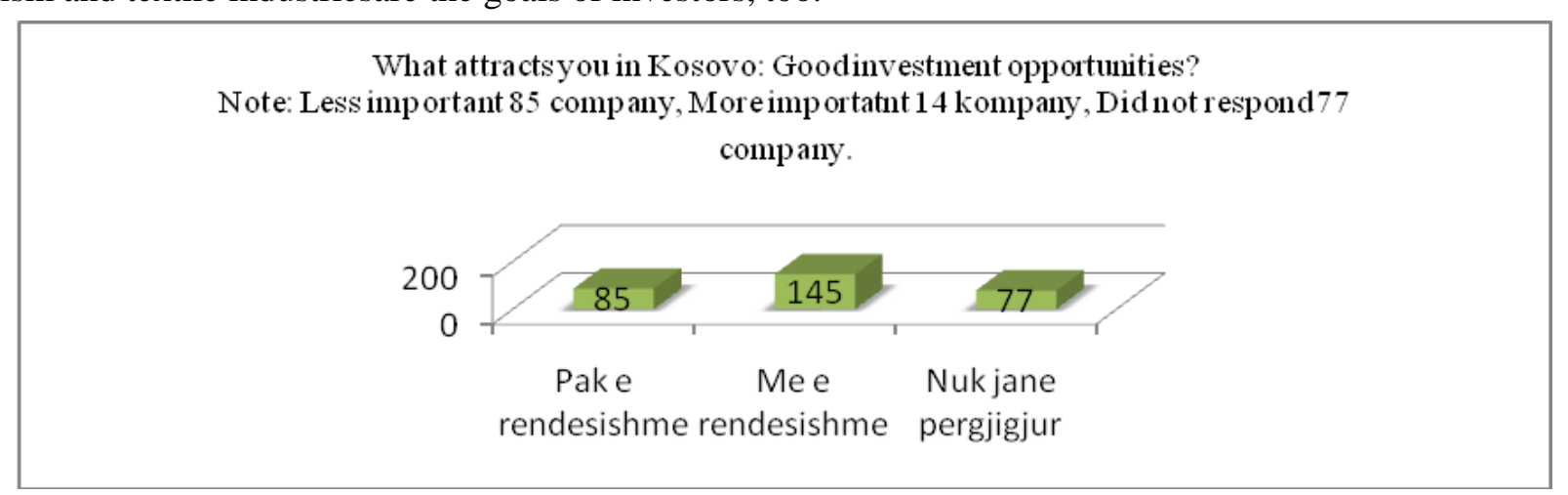

Fig. 4: Good investment opportunities.

- Good investment opportunities, foreign investors believe that Kosovo has good potential to offer and according to them by improving the infrastructure, law and by EU integration they will create major advantages in comparison with neighboring countries. The quote of 145 companies or 47.3 percent of them consider investment opportunities in Kosovo as the most important, 85 companies or 27.7 percent consider them as less important, while 77 companies or 25 percent of them did not respond.

- The central location in the region, according to invetitors' estimation Kosovo has a short distance from neighboring countries and other European countries. This enables access to 20 million regional consumers and 520 million European consumers.It is considered the center that connects East and West, being connected to the NationalHighway, it is considered that within 2 hours it can reach the Durres harbor. So, 80 companies or 26 percent of them consider this factor as important, 140 companies or 46 percentas less important, while 86 companies or 28 percent of themdid not respond. 


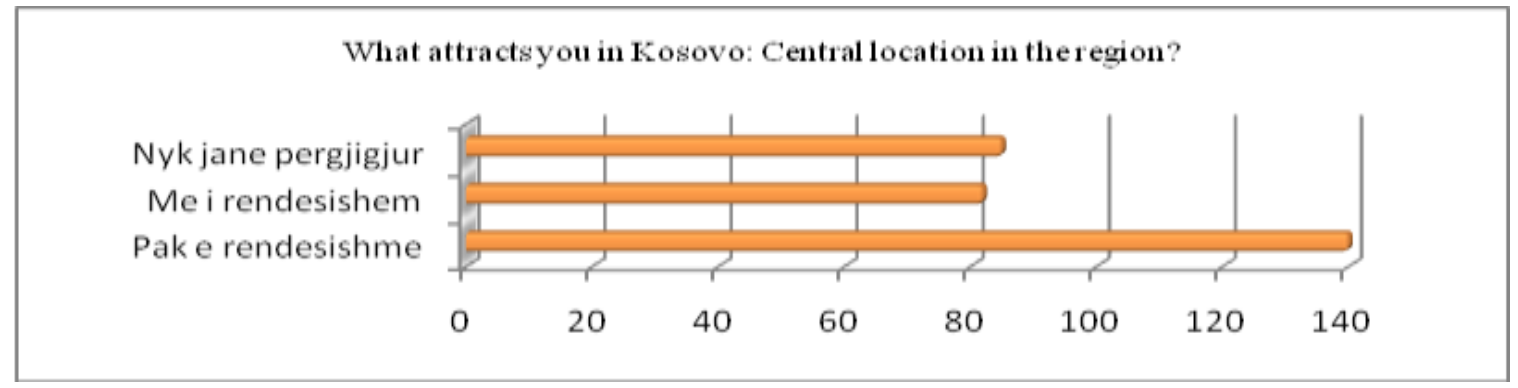

Fig. 5: Central location in the region.

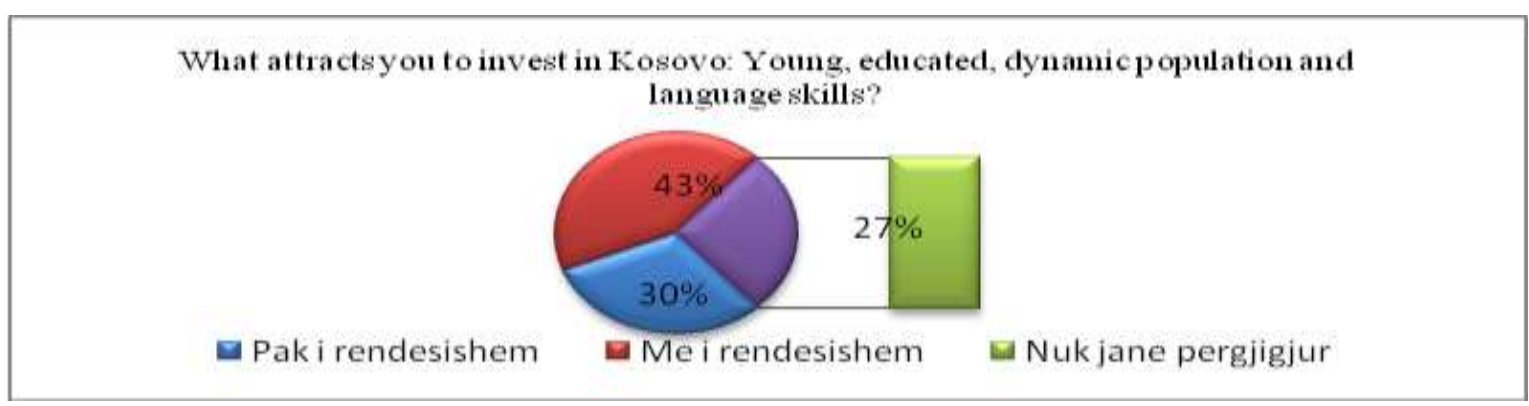

Fig. 6: Young, educated and dynamic population.

- Young, educated and dynamic population,place Kosovo under the spotlight at a time when other nations have an aging population. This way young and educated can easily use more advanced technology by reducing the cost of their training. Positively responded 43 per cent of companies, while 30 percent of them do not consider these factors important. There are 27 percent of the companies that did not respond.

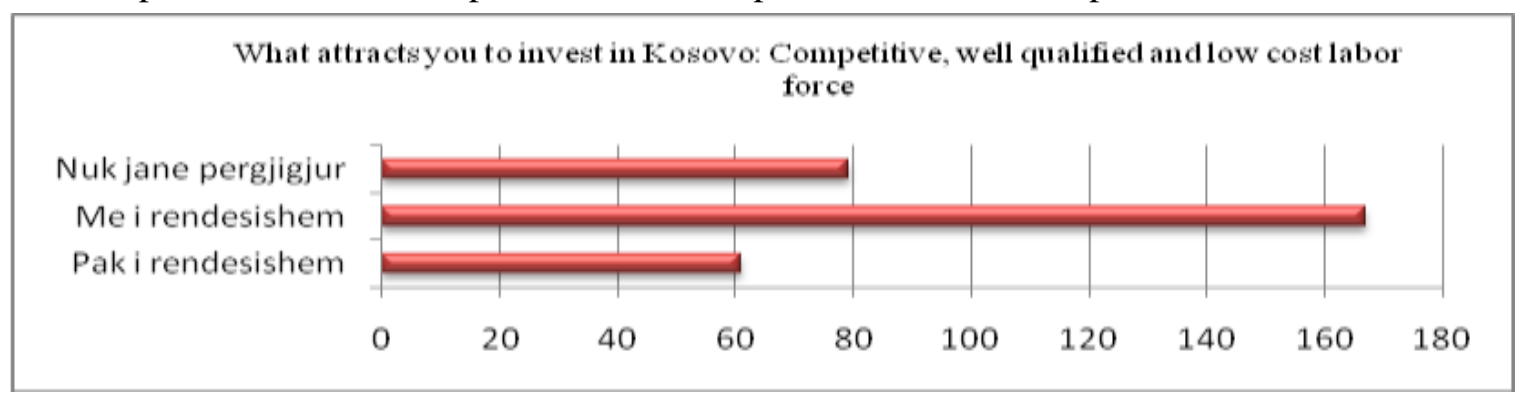

Fig. 7: Competitive, well qualified and low cost labor force.

- Competitive, well qualified and low cost labor force,encourages foreign investors to invest in finding a workforce with low cost by reducing the cost of production. With the average salary of 360 euros in public administration, while in the private sector for 30 percent lower, the minimum wage is 130 euros, Kosovo is competitive with most neighboring countries except Albania.Skilled and low-cost labor force is considered important by 170 companies or 56 percent, as less important 70 companies, or 23 percent, while 66 companies or 21 percent of them did not respond.

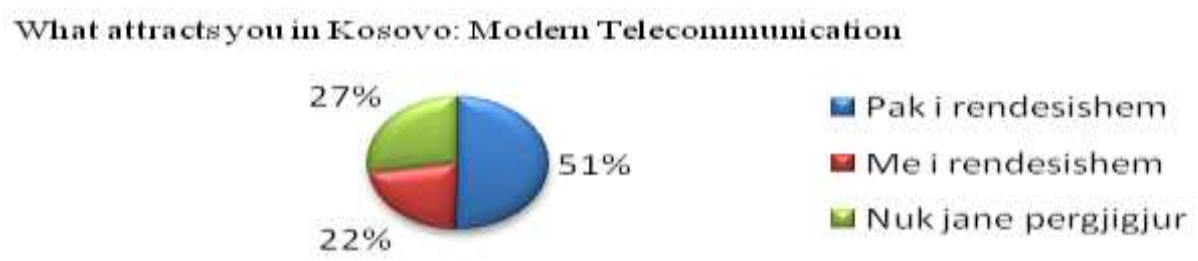

Fig. 8: Modern Telecommunications.

- Modern Telecommunications,- Modern Telecommunications, in the near future Kosovo will be deemed to be covered 100 percent by network telecommunication on all lines and road networks. Now mobile network only has this coverage degree (100\%). As important is considered by 22 percent of respondents, as less important 51 percent, while 21 companies did not give their opinion. 
- Modern legislation compatible with that of the EU, the majority of investors seek improvementof the investment law and other laws they meet in their activity. Law system in Kosovo is similar to the EU law, but its implementation is far from European standards.

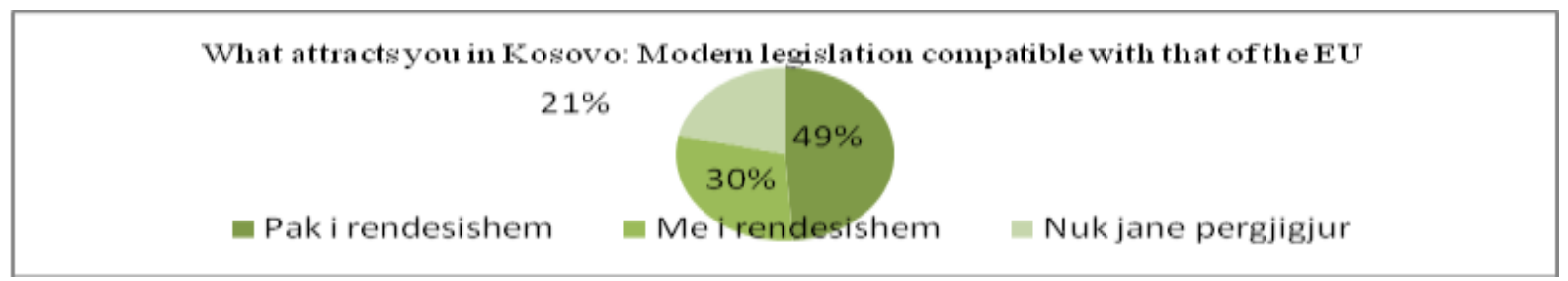

Fig. 9: Modern legislation compatible with that of the EU.

The opinion of investors about the importance of laws is 30 percent, while 49 percent give no importance. 21 percent of companies did not answer to this question.

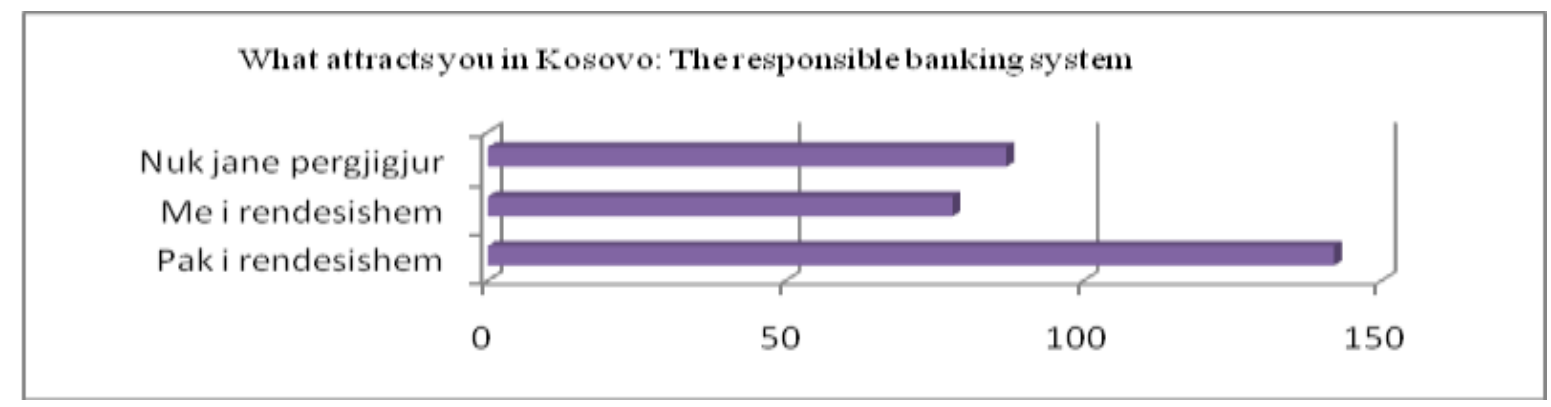

Fig. 10: The responsible banking system.

- The responsible banking system, investors point out that the banking system will be more responsible with the launch of new commercial banks. Creation of competition will lower the high interest and create larger access to local and foreign businesses in loans with low rates. It also will reduce the requirements for the provision of credit through mortgagein high values in relation to the value of the loan. The banking system as responsible is considered by 75 companies or 26.5 percent, as less responsible by 150 companies or 49 percent, while 81 companies or 24.5 percent did not respond.

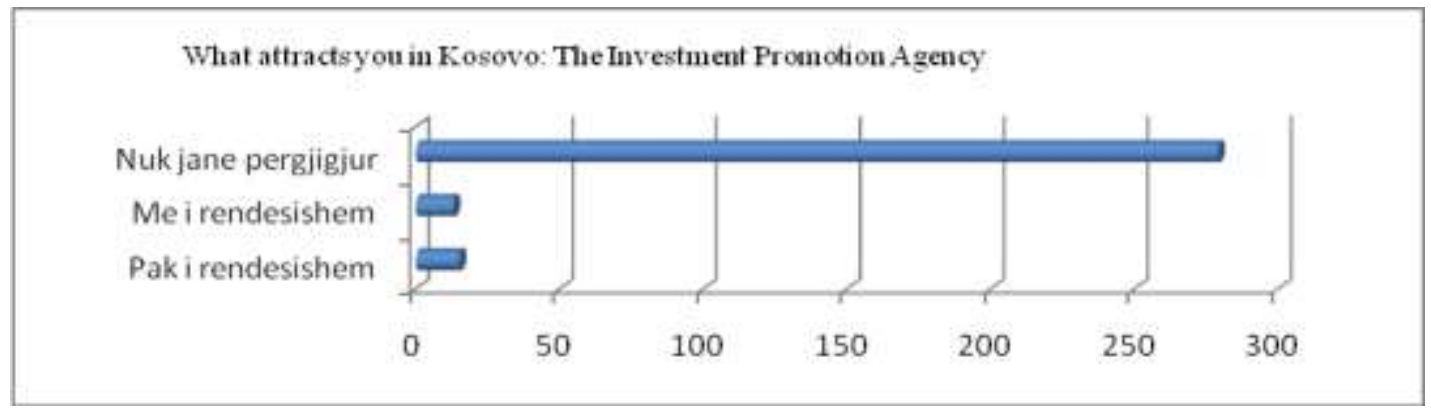

Fig. 11: The Investment Promotion Agency (IPAK).

-The Investment Promotion Agency, informs, advises, assists and promotes the country. IPAK as governmental agency eventhough in charge with this role, it does not work sufficiently in this regard because it has no sufficient and well-trained staff and sufficient budget. From the survey of 306 foreign companies, 280 companies or 91.5 percent of themdid not respond. Initially information on Kosovo they have received through other channels (Internet, television, Kosovo Privatization Agency, colleagues, social networks, friends). The survey of 280 companies on which source of information about Kosovo had been available to them, they have indirectly answered that they had followed conferences, seminars and publications outside Kosovo organized by MTI, IPAK and ECIK in Austria, Germany and Switzerland. They also point out that after these contacts, all necessary consultations and information they receive from this agency. But Kosovo lacks special events within it with foreign investors that would promote certain sectors of the economy of Kosovo. Only 20 companies or 6.5 percent of them point out as useless the information of IPAK within Kosovo, while 6 companies or 2 percent estimate the main source of information the foreign investorsreceive at the first contact with Kosovo.

- Additional investment in Kosovo in 2015, from a total of 306 respondents asked whether they have an exact date to invest in the following year (2015), 120 companies or 39.2 percent answered that would invest in 
Kosovoagain, 115 companies or 37.6 percent did not see as reasonable to invest again in Kosovo, 58 companies or 18.9 percent of those who contracted the work to invest in January 2015, with the possibility of expansion of these projects up to 2018 (the construction sector, mining, processing industry etc.), while 13 companies or 4.2 percent of themdid not respond.

- The investment quantity that foreign investors will do, is insufficient to meet the lack of capital in Kosovo according to their plans.How much they would invest, 17 companies or 5.6 percent did not respond, whereas 253 companies or 82 percent of them responded that they would invest 1-10 million euros and the same amount they would invest in the next 3 years. Of 306 foreign companies 23 companies ( 7 percent) responded that they had invested 10 to 50 million euros and the following year they would invest only 40 percent of their profits, while 60 percent of their profit they would repatriate. 14 foreign largest companies (5 percent of companies) emphasized that they had invested in Kosovo over 50 million euros and they would invest only 30 percent of their capitalin the following year. These companies have indicated that they reinvest 70 percent of their earnings in Kosovo and only 30 percent in the country of origin for the following 3 years. How much they have invested in Kosovo and if they would invest in 2015onwards, 6 percent did not respond.

- Reasons why foreign investors are reluctant to invest in Kosovoare ranked as follows: Infrastructure and physical environment 54 companies or 10 percent of them. Political environment isconsidered as an obstacle by 125 companies or 22 percent of them, bureaucratic procedures 207 companies or 37 percent of them, corruption and nepotism 127 companies or 23 percent of them and trade restrictions 46 companies or 8 percent.

- Government incentives to attract investment, administrative governmental reformsare considered important by 87 businesses and 15 percent of companies, reforms of tax administration 166 companies or 28 percent, reforms of the educational system 61 companies or 11 percent of them, the simplification of procedures of building permits 131 companies or 22 percent and stringent measures to ban corruption 141 companies or 24 percent.

\section{Conclusion}

Kosovo has liberalized the entry of FDI and pursues policies to attract investments. The first FDI came through privatization, in the form of mergers while acquisitions (Greenfield), became more common after 2004. The choice of mode of entry of FDI in Kosovo is dependent on privatization and the conditions of the country, natural resources and human capital. Net FDI inflow has peaked with 440.7 million euros in 2007, while a rapid decline to 151.2 million euros in 2014. Such a decrease of foreign investments has contributed to economic growth not to be at the expected level. By March 2015, FDI are 87.1 million euros.FDI are seen as an opportunity to increase the capital in the country, however in certain sectors it is disputable. Therefore a prudent decision must be taken by the government, by analyzing the requirements of sectors and decide to increase the FDI limits in the sectors that create higher productivity.

\section{* The reasons why we should be friendly to FDI, are numerous:}

Foreign direct investment except cash flow increase tax revenue for the country's budget,Those revenues can be reinvested in other public sectors such as health, education, environment, etc. It is tooimportant the GDP rate increase, because people consume more goods and services, increase the standard of their lives, surplus goods are exported benefiting from rising exchange abroad. With a higher GDP, the image of the country will be more positive, the country's development flow follows the right direction, increasing foreign investment in the country, too. People face more easily expenses.shpenzimet. To overcome competitive obstacles in the country, local firms may start cooperation with foreign firms. Government of Kosovo (host), haveto adopt policies that promote the right social and environmental principles of foreign companies so that damaging effects of FDI can be avoided.

\section{Integral parts of overall reforms are:}

Macroeconomic stabilization, liberalization of the law on investment and streamlining and simplification of business regulations, combating corruption, implementation of the law and creating a friendly environment for investors. Increasing the competitiveness of local firms encouraged local firms to become more efficient by improving their performance and productivity. In Kosovo, this is the greatest contribution to revenue growth. From surveys carried out in 306 companies with $100 \%$ foreign capital, they have paid about $50 \%$ of the total tax obligations they had. Operating from 1 to 3 years, and after the state controls on taxes, foreign businesses have dampened their business activity, becoming passive businesses. Of the total 1,365 companies with foreign capital and by surveys in 306 of them, 76 of them are considered passive or about $25 \%$ of companies do not contribute to revenues in Kosovo. Investment growth is necessary to create a favorable environment for business 
development. Through opinion research of existing and potential investors in Kosovo, a lot of corncerns have been found in particular areas.

\section{It is necessary to improve some climate indicators in favor of better business:}

Difficulties in starting a business, obtaining permits and licenses in central and municipal level, protecting investors and traders across borders and enforcing contracts.

- When asked which is the area of most interest to invest, response was, Pristina about $30 \%$ or 91 companies.

- The activity that dominates is the trade $14: 45 \%$ or 44 companies, construction of roads $11.2 \%$ or 34 companies, $6 \%$, telecommunications, $5.8 \%$ consultancy services, the market research, arts and culture $10 \%$ of them or 31 companies, whereas $34 \%$ of companies did not respond.

- While $70 \%$ of them consider the business environment in Kosovo as good and reasonable, which is a very positive outlook.

- When asked what attracted them to invest, $46 \%$ answered considering the most important the educated and dynamicyouth, while 51 percent consider their cheap labor force and sufficiently educated to meet the needs of companies for work force.

- There are $39 \%$ of investor respondents who consider tax incentives significant, while incentive to invest is considered by $43 \%$ as insignificant and $40 \%$ of them institutional support as insufficient.

- As difficulty is considered corruption and nepotism, bureaucratic procedures by $65 \%$ of them, while $31.4 \%$ consider poor infrastructure.

- As necessary government actions are considered: the lack of law enforcement $7 \%$, informal economy $7 \%$, professionalism $8 \%$, agriculture incentives $8 \%$, tariff and customs laws $8 \%$, outstanding trade disputes $7 \%$, etc.

- The administrative reforms are considered useful by $37 \%$, removal of procedures $52 \%$, the opportunity to invest only $41 \%$ of investors and $59 \%$ said they would not invest again in Kosovo.

- Areas of interest to invest are road transport and road construction $48 \%$, mining $7 \%$, agriculture $9 \%$, food industry $3 \%$, textile $5 \%$, etc.

- The investment quantity that can be made up to 10 million euros $82 \%$ of companies, up to 50 million euros $7 \%$, over 50 million euros $5 \%$ and $6 \%$ did not answer.

\section{* FDI effects are more positive than negative:}

- First, foreign investment means a foreign currency has entered Kosovo. Exchange reserves with other countries are increased, which are good for the host country, whichcan be used on debt payments or any imports.

- Second, more goods and services have been produced, which can be exported to foreign countries, the overall revenues increase through exports.

- Third, industrial development of Kosovois encouraged.

- Fourth, technology has been transferred, skills and technical and entrepreneurial expertise, many fully automated factories have been built, decreasing the average cost, making the production process more efficient.

- Fifth, local firms are motivated by improving the quality of their product and service based on international standards.

\section{References}

[1] Charles L. Vehorn. Vasarevic.A. (2011).FDI and Macroeconomic Policies in Central and Eastern European Countries. 24-25. International Review of Economics \& Business, Vol. 14,No. 2, pp. 23-34, 2011. Zagreb

[2] Dunning John H. (2004): "Institutional Reform, FDI and European Transition Economies", Dunning, J., Holly Dell.,SatwellClose., Rotherfield Greys., Henley-on-Thames. (2001). The Eclectic (OLI)\Paradigm of International Production: Past, Present and Future.pp.1-19.

[3] Eleni, A. Kaditi.(2010).Foreing Investment and Institutional Convergence in Sowtheaster Europe. pp.LICOS centre for Institutions and Economic Performance.www.econ.kuleuven.be

[4] Hymer S. (1960). "International Operations of National Firms: A Study of Direct Foreign Investment",Doctoral Dissertation, Massachusetts Institute of Technology.

[5] Kaufmann, D.(2012): “Corruption in Transition: reflections and implications from governance empirics", Plenary session on Measurement and Consequences ofCorruption at the Economic Research Forum in Cairo, Egypt, March 25th, 2012. 
[6] CBK (2015). Annual Report 2014. pp 23,43.http://bqk-ks.org/repository/docs/2015/Report

[7] ECIKS 2013. A new agreement for Kosovo-Providing of Sustainable Economic Increase. Pp.1.

[8] IMF.2013. Country Report No.23.Republic of Kosovo. Article IV Consultation.pp.2-4-19

[9] Kosovo Assembly, 2006.Law No. 02/L-33 for Foreign Investments, pp. 3-6.

[10] KPMG(2013). Cutting Through Complexity: Investment in Kosovo.pp.2-12.

[11] MTI (2014). MTI (2014). KPI of Kosovo.Departamentof Industry.pp.12-23.

\section{Source online:}

http://www.bqk-kos.org/

http://www.invest- ks.org

https://ask.rks-gov.net/

www.mti-ks.org/ 